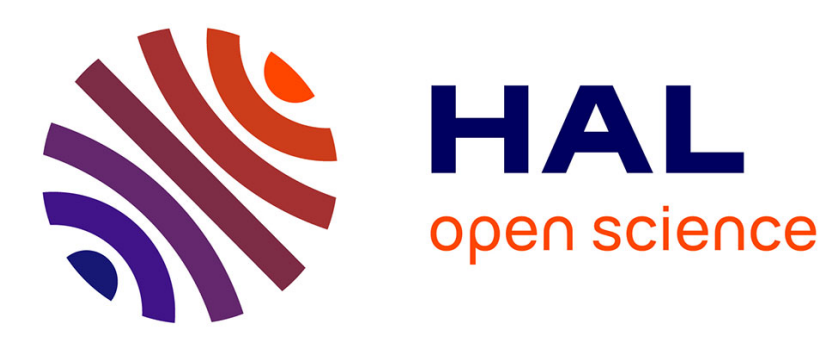

\title{
A review of the genus Eristophyton, with special focus on the Mississippian species.
}

\author{
Anne-Laure Decombeix, Brigitte Meyer-Berthaud, Jean Galtier
}

\section{To cite this version:}

Anne-Laure Decombeix, Brigitte Meyer-Berthaud, Jean Galtier. A review of the genus Eristophyton, with special focus on the Mississippian species.. Comptes Rendus. Palevol, 2007, 6 (6-7), pp.393-401. 10.1016/j.crpv.2007.09.011 . halsde-00819184

\section{HAL Id: halsde-00819184 https://hal.science/halsde-00819184}

Submitted on 30 Apr 2013

HAL is a multi-disciplinary open access archive for the deposit and dissemination of scientific research documents, whether they are published or not. The documents may come from teaching and research institutions in France or abroad, or from public or private research centers.
L'archive ouverte pluridisciplinaire HAL, est destinée au dépôt et à la diffusion de documents scientifiques de niveau recherche, publiés ou non, émanant des établissements d'enseignement et de recherche français ou étrangers, des laboratoires publics ou privés. 


\title{
A review of the genus Eristophyton, with special focus on the Mississippian species.
}

\author{
A.-L. Decombeix ${ }^{1}$, B. Meyer-Berthaud ${ }^{2}$, J.Galtier ${ }^{2}$ \\ ${ }^{1}$ corresponding author. UM2, UMR AMAP (botAnique et bioinforMatique de l'Architecture des \\ Plantes), \% CIRAD, TA-A51/PS2, Boulevard de la Lironde, 34398 Montpellier cedex 5, France \\ ${ }^{2}$ CNRS, UMR AMAP, F-34398 Montpellier.
}

\begin{abstract}
The genus Eristophyton is founded on woody axes of Mississippian age, showing a dense wood with an araucarioid type of pitting on the radial walls of tracheids and small numerous pits in crossfields. Distinctive characters of Eristophyton are related to its primary vascular body, especially the structure and arrangement of primary xylem strands, and structure and size of leaf traces. Species described from Permian deposits are not considered in this review, which focuses on the three Mississippian species, E. beinertianum, E. fasciculare, and E. waltonii. Eristophyton consists of plants of arborescent stature that produced a large amount of vascular and cortical secondary tissues, and had their leaves borne on the youngest axes. Anatomical and morphological similarities with Bilignea and Pitus are emphasized. Compared to all other arborescent genera of lignophytic affinities known for the Mississippian, Eristophyton has the widest geographical and stratigraphical extent.
\end{abstract}

Key-words: Lignophytes, trees, Mississippian, Europe, anatomy.

\section{Résumé}

Le genre Eristophyton est basé sur des axes ligneux d'âge Mississippien possédant un bois dense avec des ponctuations araucarioïdes sur la paroi radiale des trachéides et de nombreuses petites ponctuations dans les champs de croisement. Les caractères distinctifs d'Eristophyton sont liés à son système vasculaire primaire, en particulier à la structure et à la disposition des faisceaux de xylème primaire et la structure et la taille des traces foliaires. Les espèces décrites dans des horizons Permiens ne sont pas traités dans cet article qui se focalise sur les trois espèces du Mississippien E. beinertianum, E. fasciculare, E. waltonii. Eristophyton comprend des plantes arborescentes qui produisaient une grande quantité de tissus secondaires vasculaires et corticaux et portaient des feuilles seulement sur les axes jeunes. Les ressemblances anatomiques et morphologiques avec Bilignea et Pitus sont soulignées. Comparé aux autres genres arborescents du Mississippien affiliés aux lignophytes, Eristophyton est celui qui présente la plus large distribution géographique et stratigraphique.

Mots-clés : Lignophytes, arbres, Mississippien, Europe, anatomie. 
NOTICE: This is the author's version of a work accepted for publication by Elsevier. Changes resulting from the publishing process, including peer review, editing, corrections, structural formatting and other quality control mechanisms, may not be reflected in this document. Changes may have been made to this work since it was submitted for publication. A definitive version was subsequently published in Comptes Rendus Palevol, [VOL\#6, ISSUE 6-7, p.393-401], November 2007, DOl:10.1016/j.crpv.2007.09.011

\section{Introduction.}

One of the most important events in the evolution of the lignophytes, the monophyletic group of plants that includes the free-sporing progymnosperms of the Palaeozoic and the spermatophytes (seed plants), is the apparition of the seed-habit during the Devonian [4]. This reproductive innovation enabled the dispersion and establishment of plants away from wet habitats and allowed the evolution of new ecosystems. A significant diversification of ovules is now well established for the Late Devonian (Upper and Uppermost Famennian, ca $375-360 \mathrm{Myr}$ ) $[8,17,28]$, but until now, there is no evidence that a similar diversification of the vegetative morphology and architecture of early spermatophytes occurred in parallel. Famennian spermatophytes are reconstructed as small, pioneer plants growing in new and disturbed habitats $[5,6,35]$. At that time most forests were dominated by their closest known relative [29], the heterosporous progymnosperm Archaeopteris/Callixylon that achieved a modern gymnosperm type of vegetative body $[25,26]$, but got extinct close to the Devonian/Carboniferous boundary.

For the Early Carboniferous (Mississippian, ca 360-318 Myr), there is a significant fossil record of small, semi-self supporting [30] spermatophytes with a maximum diameter of a few centimetres. These plants, assigned to the Calamopityaceae, Buteoxylonaceae and Lyginopteridaceae [9], are believed to be close to the Famennian spermatophytes in terms of growth forms. On the other hand, a growing record of arborescent taxa provides evidence that large lignophyte trees were also present in Early Carboniferous landscapes. These taxaabout 15 genera - are represented by anatomically preserved trunks and branches showing a dense type of wood, from North American and European localities [12]. Except for Bilignea, more specifically $B$. cf. solida, reconstructed as a probable hydrasperman seed plant [18], uncertainties about their reproductive structures have so far prevented their inclusion in phylogenetic analyses, leaving their affinities with the non-arborescent taxa unsolved. However, these taxa document an increase in the diversity and morphological disparity of the Mississippian lignophytes, indicating that terrestrial landscapes became probably more complex at that time.

Among these arborescent genera Eristophyton, which shares several traits of its vegetative body with Bilignea, is widely distributed both geographically and stratigraphically. Yet, it is often ignored or insufficiently understood by authors describing woody remains of lignophytes from Palaeozoic deposits. The purpose of this paper is to provide a comprehensive and updated review of this genus.

\section{History of the genus Eristophyton Zalessky}

The first specimens of Eristophyton described in the literature were wood fragments from the Mississippian (Visean) of Gl" atzisch-Falkenberg, Silesia (today in Poland), referred to as Araucarites beinertianus by Goeppert (1850) [15]. Wood was dense, with short narrow rays and tracheids with crowded multiseriate pits on their radial walls. In 1902, Scott [32] compared these specimens to a more complete fragment of axis collected by Kidston in the Tournaisian deposits of Norham Bridge, Scotland. The Scottish axis measured about $4 \mathrm{~cm}$ in diameter and had its pith and primary xylem preserved. Scott [32] proposed to name all these 
NOTICE: This is the author's version of a work accepted for publication by Elsevier. Changes resulting from the publishing process, including peer review, editing, corrections, structural formatting and other quality control mechanisms, may not be reflected in this document. Changes may have been made to this work since it was submitted for publication. A definitive version was subsequently published in Comptes Rendus Palevol, [VOL\#6, ISSUE 6-7, p.393-401], November 2007, DOl:10.1016/j.crpv.2007.09.011

specimens Calamopitys beinertiana. In the same paper, Scott transferred two other decorticated axes named Araucarioxylon fasciculare [31] to a new species of Calamopitys, C. fascicularis. One was collected from the Visean of Loch Humphrey Burn, the other from the Namurian of Haltwhistle, Scotland. These axes were 3 and $2 \mathrm{~cm}$ wide respectively, and both had their pith preserved. In addition to a dense wood, both $C$. beinertiana and $C$. fascicularis showed primary xylem strands strictly distributed at the periphery of the pith, whether against the secondary xylem or separated from it, but, in the later case, only by a few layers of parenchyma cells. Primary xylem strands were described as small with few, if any, metaxylem tracheids on the centripetal side. Based on a series of transverse sections through the Loch Humphrey Burn specimen of $C$. fascicularis, Scott hypothesized that leaf traces were produced by the tangential division (i.e. resulting in two strands aligned tangentially relatively to the pith surface) of the peripheral primary xylem strands. Compared to the small cauline strands, leaf traces about to enter into the wood were conspicuously enlarged and mesarch in both $C$. beinertiana and $C$. fascicularis. Finally, a fragment of bark attached to $C$. beinertiana suggested the occurrence of several layers of periderm.

In 1911, Zalessky [39] compared C. beinertiana and C. fascicularis to the type species of Calamopitys, C. saturni, and transferred the two former species to a new genus, Eristophyton. He justified this separation by the small rays of Eristophyton compared to those in thewood of $C$. saturni, and by the smaller size and tendency to endarchy observed in the primary xylem strands of Eristophyton. However, he did not provide any diagnosis for this genus.

A comprehensive diagnosis of Eristophyton was provided by Lacey [19] when he described a third species, E. waltonii, based on a 3.5-cm-wide decorticated specimen collected byWalton from the Visean of Loch Humphrey Burn. In the generic diagnosis, Lacey emphasized five traits, four related to the primary body:

- pith parenchymatous, possibly including sclerotic nests;

- absence of scattered tracheids or primary xylem strands deep in the pith;

- primary xylem strands small, peripheral, and endarch "or nearly so" in the proximal part of their course;

- leaf traces separated by short internodes, represented by a single enlarged bundle proximally;

and one trait related to the wood: secondary xylem dense, with rays commonly 1 to 2 cells wide and less than 30 cells high.

His concept of the primary vascular architecture of Eristophyton differed somewhat from that defended by Scott. Lacey did not recognize any strictly cauline strands of primary xylem from which leaf traces derived. Based on his observations of $E$. waltonii, he interpreted all the primary xylem strands viewed in cross-section as portions of decurrent leaf bases, the small endarch ones representing proximal portions and the large mesarch strands, distal parts. Lacey also noted that leaf traces in E. waltonii were occluded within the wood, indicating leaf abscission.

In 1972, Lepekhina [21] defined Eristophyton as a genus characterized by an Araucarioxylon type of secondary xylem (tracheids with an araucarioid type of radial pits, cross-field pits numerous, cupressoid), a view that fitted with previous studies on the taxon. Lepekhina 
NOTICE: This is the author's version of a work accepted for publication by Elsevier. Changes resulting from the publishing process, including peer review, editing, corrections, structural formatting and other quality control mechanisms, may not be reflected in this document. Changes may have been made to this work since it was submitted for publication. A definitive version was subsequently published in Comptes Rendus Palevol, [VOL\#6, ISSUE 6-7, p.393-401], November 2007, DOl:10.1016/j.crpv.2007.09.011

doubted about the generic affinities of Eristophyton waltonii. Her newconcept of the genus excluded the possible occurrence of sclerotic nests in the pith and included the possibility that leaf traces consist of two bundles proximally, just before entering into thewood. Her generic diagnosis therefore excluded E. beinertianum, the first species to be described and currently considered as the type species. This diagnosis was not based on re-examination of the type material but on the observation of much younger (Permian) decorticated stems from the Kuznetsk Basin, western Siberia, which she assigned to three new species, E. zalesskyi, E. leninskianum, and E. bajkainicum. One additional Permian species was described later from southern Spain under the name Dadoxylon (Eristophyton) ibericum [38]. It was founded on one fragment of silicified wood that, according to Vozenin-Serra et al., resembled the secondary xylem of $E$. waltonii, but differed by the absence of growth rings and tangential pitting, and by smaller rays. These authors justified their double generic nomenclature by the fact that, despite a close resemblance to Eristophyton in wood features, the lack of information concerning the primary body of the specimen prevented its certain assignation to this particular genus.

Further reports on the genus concentrated on Mississippian species and implicitly recognized Lacey's diagnosis as the most relevant $[2,3,7,10,13,14,23]$. They provided information on the stature and maximum size of the trunks, branching patterns, phyllotaxis, and structure of the leaf vascular supplies, leading to potential reconstructions of the Mississippian species that are presented in the following section. They also accounted for the extended geographical occurrence of Eristophyton, which is presently known from several European countries (Poland, Scotland, Germany, France) and probably North Africa [3]. Table 1 summarizes the occurrences of the genus and provides corresponding references.

\section{Systematic diversity of Eristophyton in the Mississippian}

\subsection{Eristophyton beinertianum.(Goeppert) Zalessky, 1911 (type species) (Figure 1.A)}

1850. Araucarites beinertianum GOEPPERT p. 233

1902. Calamopitys beinertiana SCOTT pp. 341-345

1911. Eristophyton beinertianum (Goeppert) ZALESSKY p.10-14

This species was first reported by Goeppert (1850) [15] from the Mississippian of Gl" atzischFalkenberg (Poland) under the generic name Araucarites (see section 2). It was subsequently redescribed by Solms-Laubach [36]. The first description including features of the stele was provided by Scott in 1902 and is based on a specimen from the Late Tournaisian of southern Scotland [32]. Further specimens of similar age were later reported from a wider range of Scottish localities by Barnard [1], Long [23], Bateman and Rothwell [2], and Scott and Galtier [10].

Specimens of E. beinertianum range from $7 \times 11 \mathrm{~mm}$ to $10 \mathrm{~cm}$ in diameter and most are decorticated [23]. Evidence for branching is rare [23]. Pith is wide, up to $1.5 \mathrm{~cm}$ in the Polish specimen [32]. It contains conspicuous sclerotic nests (Fig. 1A). Primary xylem strands 
NOTICE: This is the author's version of a work accepted for publication by Elsevier. Changes resulting from the publishing process, including peer review, editing, corrections, structural formatting and other quality control mechanisms, may not be reflected in this document. Changes may have been made to this work since it was submitted for publication. A definitive version was subsequently published in Comptes Rendus Palevol, [VOL\#6, ISSUE 6-7, p.393-401], November 2007, DOl:10.1016/j.crpv.2007.09.011

are about $150 \mu \mathrm{m}$ wide, numerous (at least 17 in the specimen from Norham Bridge) and partly confluent. They are located in contact with the secondary xylem [32]. Leaf traces are large, up to $800 \mu \mathrm{m}$ in transverse section. During their course through the wood they remain undivided and show one mesarch strand of protoxylem [31]. Their pattern of emission is unknown. Rays in the wood are generally uniseriate, rarely locally biseriate. They are short, often 1 to 2 cells high, up to 26 cells [31]. A fragment of bark still attached to the Norham Bridge specimen shows alternating bands of light and dark cells [31].

In 1990, Galtier \& Scott described a spiral arrangement (3/8 phyllotaxis) of leaf traces in a $4 \mathrm{~cm}$ wide specimen from East Lothian that had its pith destroyed [10]. In this axis, referred to as Eristophyton cf. beinertianum, the protoxylem strand in the traces divides in 2 then 3 strands outwardly. Internode length is about $8 \mathrm{~mm}$.

\subsection{Eristophyton fasciculare (Scott) Zalessky, 1911. (Figure 1.B, D, E)}

1899. Araucarioxylon fasciculare SCOTT p. 615.

1902. Calamopitys fascicularis SCOTT pp. 332-341

1911. Eristophyton fasciculare (Scott) ZALESSKY pp. 10-14

This species was first described by Scott [32] from two Scottish localities: Loch Humphrey Burn (Early to Middle-Visean) and Haltwhistle (Namurian A). The two specimens were decorticated. Other Scottish specimens were then reported from the Upper Visean localities of Weaklaw and East Kirkton by Galtier et al. [14] and Galtier and Scott [11].

The maximum diameter reported for E. fasciculare is $6 \mathrm{~cm}$ and all known specimens are interpreted as branches [11]. Pith in these specimens contrasts with that in E. beinertianum and E. waltonii by its small size (Fig. 1B), 2-3mm in diameter only, and by the absence of sclerotic nests. The pith contains large cells with dark contents. Primary xylem strands are relatively few, 14 being themaximumnumber recorded [11]. These strands do not exceed 200 $\mu \mathrm{m}$ in width [14]. They are discrete and separated from the secondary xylem by a few layers of parenchyma cells. Leaf traces are large, $1 \mathrm{~mm}$ in maximum diameter, circular in transverse section and contain one mesarch protoxylem strand when entering into the wood [32]. They remain undivided until they get occluded. At this point they may show up to 3 protoxylem strands [11] (Fig. 1D). Leaf traces are emitted in close spiral from the tangential division of small peripheral primary xylem strands, a pattern described by Scott (1902) [32] and later supported by Galtier and Scott [11]. Internode length is short, estimated at about 2.5mm [11]. Rays in wood are commonly uni- to partly biseriate, up to three cells wide and 35 cells high [14,32] (Fig. 1E).

Ontogenic variations in the secondary xylem have been studied by Galtier and Scott [14] on 8 specimens. From the pith to the external part of the wood, tracheid diameter increases and ray density decreases. The average ray size does not change significantly. The secondary phloem contains fibres arranged in tangential bands of 3-4 cells alternating with bands of thin-walled cells, some with dark contents. Phloem rays enlarge tangentially towards the periphery [11]. Periderm was reported but not described [14]. 
NOTICE: This is the author's version of a work accepted for publication by Elsevier. Changes resulting from the publishing process, including peer review, editing, corrections, structural formatting and other quality control mechanisms, may not be reflected in this document. Changes may have been made to this work since it was submitted for publication. A definitive version was subsequently published in Comptes Rendus Palevol, [VOL\#6, ISSUE 6-7, p.393-401], November 2007, DOI:10.1016/j.crpv.2007.09.011

\subsection{Eristophyton waltonii (Lacey) Galtier and Scott, 1990. (Figure 1.C, F)}

This species, initially described by Lacey (1953), was based on a 3.5-cm-wide decorticated specimen from the Visean of Loch Humphrey Burn [19]. It was subsequently reported from several other Scottish localities, some older in age [23]. Galtier and Scott (1990) emended the diagnosis to include additional information on the structure of the leaf traces and that obtained from large specimens [10].

Specimens of Eristophyton waltonii range from 1.2 to $24 \mathrm{~cm}$ in diameter [23]. Pith size varies accordingly from $3.5 \times 5 \mathrm{~mm}$ in the smaller specimen to more than $3 \mathrm{~cm}$ in the larger ones. The wide pith of Eristophyton waltonii is characterized by conspicuous sclerotic nests like in $E$. beinertianum (Fig. 1C). Primary xylem strands are very small compared to those in $E$. beinertianum and E. fasciculare (Fig. 1C) and are numerous (10 to more than 40) [10]. Their number increases with the size of the pith. They are discrete, either lying in contact with the secondary xylem or separated from it by some layers of parenchyma cells (Fig. 1C). According to Lacey [19], all the primary xylem strands correspond to individual leaf traces (see Section 2 above). Such strands may be as small as $70 \mu \mathrm{m}$ wide proximally and are less than $250 \mu \mathrm{m}$ when about to enter the secondary xylem [10]. Leaf traces crossing the wood are surrounded by some secondary xylem proximally. In the type specimen, leaf traces remain undivided until they get occluded at a small distance from the pith (less than $3 \mathrm{~mm}$ ) [19]. In a small specimen later described from the Tournaisian of East Lothian, however, one of the leaf traces was followed outside the secondary xylem where it divides into 6 vascular strands arranged in an arc [23]. Another small specimen from Oxroad Bay tentatively assigned to $E$. waltonii also showed leaf traces subdivided into 6 vascular strands, together with a possibly attached petiole base of Lyginorachis type [23]. Monopodial branching has been demonstrated in E. waltonii, but there is no direct evidence of an axillant leaf [10]. The secondary xylem in E. waltonii is characterized by rays that are both wider and higher than those in the two other Mississippian species. Rays are 1-7 cells wide and up to 50 cells high (commonly 30) [10] (Fig. 1F). Other characters that, up to now, appear specific to the wood of E. waltonii are the occurrence of vertical parenchyma, of growth rings, and pitting that may occur on the tangential walls of tracheids located near the pith and in the late wood.

\subsection{Possible new species}

Distinction between the three Mississippian species is based on four easily observable characters:

- presence/absence of sclerotic nests in the pith;

- position of primary xylem strands relatively to the secondary xylem;

- maximum size of the primary xylem strands and leaf traces;

- ray size.

Other characters that are more variable, such as the presence/absence of vertical parenchyma in the wood, or of tangential pits on the walls of secondary xylem tracheids, are more rarely used. Despite the clear-cut differences mentioned above, there are at least two cases of Mississippian specimens showing an original combination of characters that are suspected to 
NOTICE: This is the author's version of a work accepted for publication by Elsevier. Changes resulting from the publishing process, including peer review, editing, corrections, structural formatting and other quality control mechanisms, may not be reflected in this document. Changes may have been made to this work since it was submitted for publication. A definitive version was subsequently published in Comptes Rendus Palevol, [VOL\#6, ISSUE 6-7, p.393-401], November 2007, DOl:10.1016/j.crpv.2007.09.011

represent new species. The first one is a specimen from the Upper Tournaisian of Oxroad Bay referred to as Eristophyton cf. waltonii by Galtier and Scott [10]. This decorticated specimen has a wood with very small rays, consistent with that of E. beinertianum and E. fasciculare. However, its primary vascular anatomy, considered as more significant systematically by the authors, is similar to that of E. waltonii. The pith contains sclerotic nests. Primary xylem strands are numerous, some not in contact with the secondary xylem. Leaf traces are small and surrounded by some secondary xylem.

The second case corresponds to a specimen named Eristophyton sp. from the Middle Tournaisian of Kahlleite, Germany [7]. This specimen, again, has a wood with small rays comparable to E. beinertianum and E. fasciculare. Primary xylem strands and leaf traces are small like in E. waltonii [14]. These strands are always in contact with the wood, like in $E$. beinertianum, and the pith is devoid of sclerotic nests, like in E. fasciculare. Other decorticated specimens showing the same combination of characters are found in coeval deposits of the Montagne Noire (southern France).

\section{Reconstruction of Eristophyton}

Whatever their specific affinities, the Mississippian axes of Eristophyton show a conspicuous amount of dense wood surrounding a central pith. The occurrence of an external periderm was demonstrated in E. beinertianum and E. fasciculare. A similar organization in Pitus dayi produced a biomechanical signal consistent with a self-supporting habit [36]. We therefore hypothesize that Eristophyton consisted of self-supporting plants. At present, there is no direct evidence that $E$. fasciculare, represented by specimens of moderate diameter, comprised any trees. The maximum diameter of $10 \mathrm{~cm}$ reported for an axis of E. beinertianum indicates that this species comprised at least small trees. However, the best evidence for a tree habit in the genus was provided by axes exceeding $20 \mathrm{~cm}$ in diameter in E. waltonii. Application of the allometric relationships established by Niklas [27] for woody stems suggests that the largest specimens of $E$. waltonii reached 20 meters in height.

Leaves in the three Mississippian species of Eristophyton are produced helically and are separated by short internodes [10,11,19]. Leaf traces in E. fasciculare and E. waltonii are occluded in the wood after a course of variable length indicating that leaves were abscissed as the axes enlarged in diameter and produced more secondary tissues [13]. The occurrence of a periderm in E.beinertianum suggests that, in this species too, leaves were borne distally, on young shoots only. The best evidence for the type of leaves borne on Eristophyton was brought by Long [23] from the study of 2 young axes of $E$. waltonii in which leaf traces were followed beyond the secondary xylem. Leaf traces in this species subdivided distally into six separate strands resembling the vascular organization at the base of Lyginorachis waltonii Calder, a petiole found in the same deposits. Evidence was not as clear in E. beinertianum and E. fasciculare, but division of the protoxylem strand in the distalmost-preserved parts of leaf traces suggests a comparable pattern for these species. Long then suggested that Eristophyton, Lyginorachis waltonii and Diplotmema (foliage preserved in compression), which all possess sclerotic nests, were closely related. 
NOTICE: This is the author's version of a work accepted for publication by Elsevier. Changes resulting from the publishing process, including peer review, editing, corrections, structural formatting and other quality control mechanisms, may not be reflected in this document. Changes may have been made to this work since it was submitted for publication. A definitive version was subsequently published in Comptes Rendus Palevol, [VOL\#6, ISSUE 6-7, p.393-401], November 2007, DOl:10.1016/j.crpv.2007.09.011

Galtier and Scott (1990) [10] supported the hypothesized relationship between Eristophyton and Lyginorachis waltonii. Based on the relative size of leaf traces, however, these authors suggested that $L$. waltonii was more closely related to the axis they called Eristophyton cf. beinertianum than to $E$. waltonii. In a later paper describing plant remains from the Visean locality of Weaklaw, Galtier et al. [13] showed that the anatomy of Spathulopteris obovata (foliage in compression) corresponded to that described for Lyginorachis kingswoodense [24] and suggested that such remains represented the foliage of one of the arborescent lignophytes of the locality, i.e. either Pitus withami or Eristophyton fasciculare.

\section{Affinities of Eristophyton.}

Within the informal group of Mississippian lignophytes producing a large amount of dense wood, all the specimens assigned to Eristophyton are united by a distinctive set of characters related to the primary vascular system. These are:

(i) the absence of tracheids and xylem strands deep in the pith;

(ii) primary xylem strands tending to be endarch in the lower part of their course;

(iii) leaf traces mesarch and enlarged compared to other primary xylem strands;

(iv) leaf traces undivided proximally and arranged in a close spiral;

(v) leaf trace emission not involving the radial division of a xylem strand.

The later character is ambiguous and refers to the contrasting patterns described in $E$. fasciculare (leaf traces emitted from the tangential division of a cauline strand) and $E$. waltonii (all primary xylem strands suspected to be of foliar origin). In any case, each of these patterns corresponds to a derived condition compared to that observed in the progymnosperms and earliest seed plants like Elkinsia [9]. However, this double possibility raises doubts about the systematic consistency of Eristophyton as representing a single genus.

Bilignea and Pitus often co-occur with Eristophyton in Late Tournaisian and Visean localities of Scotland [2,10,11,13,14,16,22,34]. Their resemblance, whether anatomical or morphological, has been emphasized in many reports. In terms of habit, the three genera are considered as arborescent, producing closely arranged leaves on the younger axes or twigs. Leaves were shed as the axes increased in diameter and produced secondary cortical tissues. Their proximal part, or petiole, was of the Lyginopteris-type, the later trait more specifically observed in E. waltonii, Bilignea cf. solida, and Pitus dayi [9,18,22]. Anatomically, features (ii)-(v) cited above for Eristophyton are also encountered in Bilignea solida [34]. However, in this species, the pith is replaced by a column of short pitted cells that may have a role in water storage. Pitus differs from Eristophyton in several characters of the primary vascular system such as the occurrence of primary xylem strands in the pith or strictly mesarch primary xylem strands. The wood of Pitus generally contains larger rays, but there can be an overlap in ray size with E. waltonii. Galtier and Scott [10] hypothesized that the three genera Eristophyton, Bilignea and Pitus formed a small natural group of gymnosperms.

In the absence of any known reproductive structures, the affinities of Eristophyton and other contemporaneous putative arborescent spermatophytes are uncertain. A possible relationship with the cordaites has been suggested by most authors $[19,22,33,34,39]$, based on the 
NOTICE: This is the author's version of a work accepted for publication by Elsevier. Changes resulting from the publishing process, including peer review, editing, corrections, structural formatting and other quality control mechanisms, may not be reflected in this document. Changes may have been made to this work since it was submitted for publication. A definitive version was subsequently published in Comptes Rendus Palevol, [VOL\#6, ISSUE 6-7, p.393-401], November 2007, DOl:10.1016/j.crpv.2007.09.011

occurrence of endarch maturation and dense wood, especially considering that of E. beinertianum and E. fasciculare.

\section{Conclusion}

Eristophyton is one of the most widely distributed arborescent lignophytes of Mississippian age and may have contributed significantly to the forested landscapes of the Carboniferous prior to the development of coal floras. The best-known species of the genus are E. waltonii and to a lesser extent $E$. fasciculare.Anumber of characters have been accumulated concerning the morphology and anatomy of these taxa that allow their partial reconstruction and should help progressing in the study of their relationships. Concerning the vegetative body of such plants, more work remains to be done on the patterns of emission of leaf traces that are not fully understood in Eristophyton but also in most of the other contemporaneous lignophytic trees. Future projects involving Eristophyton will use a phylogenetic approach to test its affinities with the seed plants and its relationships with Bilignea and Pitus.

\section{Acknowledgements}

We are very much indebted to the organizers (Profs. Armand de Ricqlès and Jean Broutin) and sponsors(Collège de France, Organisation francophone de Paléobotanique, Linnean Society Paleobotany Specialist Group) of the congress Paleobotany and the evolution of plants: current issues, for which this review paper was specially prepared.

AMAP ('BotAnique et bio-inforMatique de l'Architecture des Plantes') is a 'Unité mixte de recherche' that associates CIRAD (UMR51) with CNRS (UMR5120), INRA (UMR931), IRD (R123), and University Montpellier-2 (UM27); http://amap.cirad.fr.

\section{References.}

[1] P.D.W. Barnard, Studies on some Lower Carboniferous plants from East Lothian, PhD thesis, University of London, 1960.

[2] R.M. Bateman, G.W. Rothwell, A reappraisal of the Dinantian floras at Oxroad Bay, East Lothian, Scotland. 1. Floristics and the development of whole-plant concepts, Trans. R. Soc. Edinb.: Earth Sci. 81 (1990) 127-159.

[3] F. Chalot-Prat, J. Galtier, Découverte d'un tronc de gymnosperme dans une coulée du complexe volcanique carbonifère du Tazekka (Maroc oriental) et sa signification paléoécologique, C. R. Acad. Sci. Paris. 309 (1989) 1735-1741.

[4] P. Crane, P. Herendeen, M. Friis, Fossils and plant phylogeny, Am. J. Bot. 91 (2004) $1683-1699$.

[5] W.L. Cressler, Evidence of earliest known wildfires, Palaios 16 (2001) 171-174.

[6] W.L. Cressler, Plant paleo-ecology of the Late Devonian Red Hill locality, north-central Pennsylvania, an Archaeopteris-dominated wetland plant community and early tetrapod site, Geol. Soc. Am. 399 (2006) 79-102 (special paper). 
NOTICE: This is the author's version of a work accepted for publication by Elsevier. Changes resulting from the publishing process, including peer review, editing, corrections, structural formatting and other quality control mechanisms, may not be reflected in this document. Changes may have been made to this work since it was submitted for publication. A definitive version was subsequently published in Comptes Rendus Palevol, [VOL\#6, ISSUE 6-7, p.393-401], November 2007, DOl:10.1016/j.crpv.2007.09.011

[7] A.-L. Decombeix, B. Meyer-Berthaud, N.P. Rowe, J. Galtier, Diversity of large woody lignophytes preceding the extinction of Archaeopteris: new data from the Middle Tournaisian of Thuringia (Germany), Rev. Palaeobot. Palynol. 137 (2005) 69-82.

[8] M. Fairon-Demaret, Dorinnotheca streelii Fairon-Demaret, gen. et sp. nov., a new early seed plant from the Upper Famennian of Belgium, Rev. Palaeobot. Palynol. 93 (1996) 217-233 (Maurice Streel) commemorative volume.

[9] J. Galtier, Morphology and phylogenetic relationships of early pteridosperms, in: C.B. Beck (Ed.), Origin and Evolution of Gymnosperms, Columbia University Press, New York, 1988, pp. 135-176.

[10] J. Galtier, A.C. Scott, On Eristophyton and other gymnosperms from the Lower Carboniferous of Castelton Bay, East Lothian, Scotland, Geobios 23 (1990) 5-19.

[11] J. Galtier, A.C. Scott, Arborescent gymnosperms from the Visean of East Kirkton, West Lothian, Scotland, Trans. R. Soc. Edinb.: Earth Sci. 84 (1994) 261-266.

[12] J. Galtier, B. Meyer-Berthaud, The diversification of early arborescent seed ferns, J. Torrey Bot. Soc. 133 (2006) 7-19.

[13] J. Galtier, J.-L. Schneider, L. Grauvogel-Stamm, Arborescent gymnosperms and the occurrence of Protopitys from the Lower Carboniferous of the Vosges, France, Rev. Palaeobot. Palynol. 99 (1998) 203-215.

[14] J. Galtier, R.E. Brown, A.C. Scott, G.M. Rex, N.P. Rowe, A Late Dinantian flora from Weaklaw, East Lothian, Scotland, J. Paleontol. 49 (1993) 57-74 (special paper).

[15] H.R. Goeppert, Monographie der fossilen Coniferen, Nat. Verh. Holl. Maatsch. Wet. Haarlem. 2 (1850) 231-233.

[16] W.T. Gordon, The genus Pitys, Witham, emend., Trans. R. Soc. Edinb. L8 (1935) 279-311.

[17] J. Hilton, Review of the fossil evidence for the origin and earliest evolution of the seedplants, Acta Bot. Sin. 40 (1998) 981-987.

[18] J. Hilton, R.M. Bateman, Pteridosperms are the backbone of seed plant phylogeny, J. Torrey Bot. Soc. 133 (2006) 119-168.

[19] W.S. Lacey, Scottish Lower Carboniferous Plants: Eristophyton waltonii sp. nov. and Endoxylon zonatum (Kidston) Scott from Dumbartonshire, Ann. Bot. 68 (1953) 579-596.

[20] V.G. Lepekhina, Paleoxylologicheskaya kharacteritika verknepaleozoiskikh uglenosnykh otlozheniy Kuznetskogo basseyna, Tr. Vsegei 130 (1969) 126-154 (special issue).

[21] V.G. Lepekhina, Woods of Paleozoic pycnoxylic gymnosperms with special reference to North Eurasia representatives, Palaeontographica Abt. B 138 (1972) 44-106.

[22] A.G. Long, Observations on the Lower Carboniferous genus Pitus Witham, Trans. R. Soc. Edinb.: Earth Sci. 70 (1979) 111-127.

[23] A.G. Long, Observations on Eristophyton Zalesski, Lyginorachis waltonii Calder, and Cladoxylon edromense sp. nov. From the Lower Carboniferous Cementstone group of Scotland, Trans. R. Soc. Edinb.: Earth Sci. 78 (1987) 73-84.

[24] B. Meyer-Berthaud, Studies on a Lower Carboniferous flora from Kingswood near Pettycur, Scotland. III. Lyginorachis, Rev. Palaeobot. Palynol. 63 (1990) 77-90.

[25] B. Meyer-Berthaud, A.-L. Decombeix, A tree without leaves, Nature 446 (2007) 861-862.

[26] B. Meyer-Berthaud, S.E. Scheckler, J. Wendt, Archaeopteris is the earliest known modern tree, Nature 398 (1999) 700-701. 
NOTICE: This is the author's version of a work accepted for publication by Elsevier. Changes resulting from the publishing process, including peer review, editing, corrections, structural formatting and other quality control mechanisms, may not be reflected in this document. Changes may have been made to this work since it was submitted for publication. A definitive version was subsequently published in Comptes Rendus Palevol, [VOL\#6, ISSUE 6-7, p.393-401], November 2007, DOl:10.1016/j.crpv.2007.09.011

[27] K.J. Niklas, The allometry of safety-factors for plant height, Am. J. Bot. 81 (1994) 345351.

[28] C. Prestianni, Early diversification of seeds and seed-like structures, Carnets de Geologie/Notebooks on geology Memoir 02 (2005), Abstract 06, 2005.

[29] G.W. Rothwell, R. Serbet, Lygnophyte phylogeny and the evolution of Spermatophytes: a numerical cladistic analysis, Syst. Botany 19 (1994) 443-482.

[30] N.P. Rowe, T. Speck, J. Galtier, Biomechanical analysis of a Palaeozoic gymnosperm stem, Proc. R. Soc. Lond. B 252 (1993) 19-28.

[31] D.H. Scott, On the primary wood of certain Araucarioxylons, Ann. Bot. 13 (1899) 615.

[32] D.H. Scott, Primary structure of certain Paleozoic stems with Dadoxylon type of wood, Trans. R. Soc. Edinb.: Earth Sci. 40 (1902) 346-357.

[33] D.H. Scott, Studies in fossil botany: Spermophyta, A. and C. Black, Ltd, London, 1923, 129-132.

[34] D.H. Scott, Fossil plants of the Calamopitys type, from the Carboniferous rocks of Scotland, Trans. R. Soc. Edinb.: Earth Sci. 53 (part III) (1924) 331-365.

[35] R. Serbet, G.W. Rothwell, Characterizing the most primitive seed ferns. I. A reconstruction of Elkinsia polymorpha, Int. J. Plant. Sci. 153 (1992) 602-621.

[36] H. Solms-Laubach, U“ ber die in den Kalksteinen des Kulm von Glatzsich-Falkenberg in Schlesien erhaltenen Strukturbilder der Pflanzenreste, Bot. Ztg Jahrg. 51 (1893) 197.

[37] T. Speck, N.P. Rowe, Biomechanical analysis of Pitus dayi: early seed plant vegetative morphology and its implications on growth habit, J. Plant Res. 107 (1994) 443-460.

[38] C. Vozenin-Serra, J. Broutin, N. Toutin-Morin, Bois permiens du Sud-Ouest de l'Espagne et du Sud-Est de la France. Implications pour la taxonomie des gymnospermes paléozoïques et la phylogénie des gingkophytes, Palaeontographica B 221 (1994) 1-26.

[39] M.D. Zalessky, Etude sur l'anatomie du Dadoxylon tchihatcheffi Geoppert, Mem. Com. Geol. Russ. 68 (1911) 1-29. 
NOTICE: This is the author's version of a work accepted for publication by Elsevier. Changes resulting from the publishing process, including peer review, editing, corrections, structural formatting and other quality control mechanisms, may not be reflected in this document. Changes may have been made to this work since it was submitted for publication. A definitive version was subsequently published in Comptes Rendus Palevol, [VOL\#6, ISSUE 6-7, p.393-401], November 2007, DOl:10.1016/j.crpv.2007.09.011

Figure 1. Anatomy of the three Mississippian species of Eristophyton.

A-C: stele and leaf traces - transverse section.

A. Eristophyton beinertianum: portion of the stele showing 2 sclerotic nests $(\mathrm{SN})$ in the pith $(\mathrm{P})$, a departing leaf trace (arrow) and secondary xylem (X2). Scale bar $=2 \mathrm{~mm}$. Specimen 677, Glasgow.

B. Eristophyton fasciculare: stele with small pith (P), primary xylem strands (black arrows) and leaf trace in the wood (LT). Scale bar $=2 \mathrm{~mm}$. Frame: detail of a primary xylem strand. Scale bar $=250 \mu \mathrm{m}$. Specimen NMS G 1993.14.41.

C. Eristophyton waltonii: portion of the stele with a sclerotic nest $(\mathrm{SN})$ in the pith $(\mathrm{P})$, two primary xylem strands (arrows) separated from the secondary xylem (X2) by parenchyma. Scale bar= 250 $\mu \mathrm{m}$. Specimen CB25.

D. E.fasciculare: leaf trace in the wood with three protoxylem poles. Scale bar $=205 \mu \mathrm{m}$. Specimen NMS G 1993.14.41.

E-F: secondary xylem in tangential section

E. E.fasciculare: uni- to biseriate rays, scale bar=250 $\mu$ m. Specimen NMS G 1993.14.41.

F. E.waltonii: uni- to quadriseriate rays, scale bar $=250 \mu \mathrm{m}$. Specimen CB01.

Figure 1. Anatomie des trois espèces d'Eristophyton du Mississippien

A-C: stèle et traces foliaires - coupe transversale

A. Eristophyton beinertianum: portion de la stèle montrant deux nids scléreux (SN) dans la moelle $(\mathrm{P})$, un départ de trace foliaire (flèche) et le xylème secondaire $(\mathrm{X} 2)$. Echelle $=2 \mathrm{~mm}$. Spécimen 677, Glasgow.

B. Eristophyton fasciculare: stèle avec une petite moelle $(\mathrm{P})$, des faisceaux de xylème primaire (flèches noires) et une trace foliaire dans le bois (LT). Echelle $=2 \mathrm{~mm}$. Encadré : détail d'un faisceau de xylème primaire. Echelle $=250 \mu \mathrm{m}$. Spécimen NMS G 1993.14.41.

C. Eristophyton waltonii: portion de la stèle montrant un nid scléreux (NS) dans la moelle (P), deux faisceaux de xylème primaire (flèches) séparés du xylème secondaire (X2) par du parenchyme. Echelle $=250 \mu \mathrm{m}$. Spécimen CB25.

D. E.fasciculare: trace foliaire dans le bois avec trois pôles de protoxylème. Echelle $=250 \mu \mathrm{m}$. Specimen NMS G 1993.14.41.

E-F: Xylème secondaire en coupe tangentielle

E. E.fasciculare: rayons uni- à bisériés. Echelle = 250 $\mu \mathrm{m}$. Spécimen NMS G 1993.14.41.

F. E.waltonii: rayons uni- à quadrisériés. Echelle $=205 \mu \mathrm{m}$. Spécimen CB01. 
NOTICE: This is the author's version of a work accepted for publication by Elsevier. Changes resulting from the publishing process, including peer review, editing, corrections, structural formatting and other quality control mechanisms, may not be reflected in this document. Changes may have been made to this work since it was submitted for publication. A definitive version was subsequently published in Comptes Rendus Palevol, [VOL\#6, ISSUE 6-7, p.393-401], November 2007, DOI:10.1016/j.crpv.2007.09.011
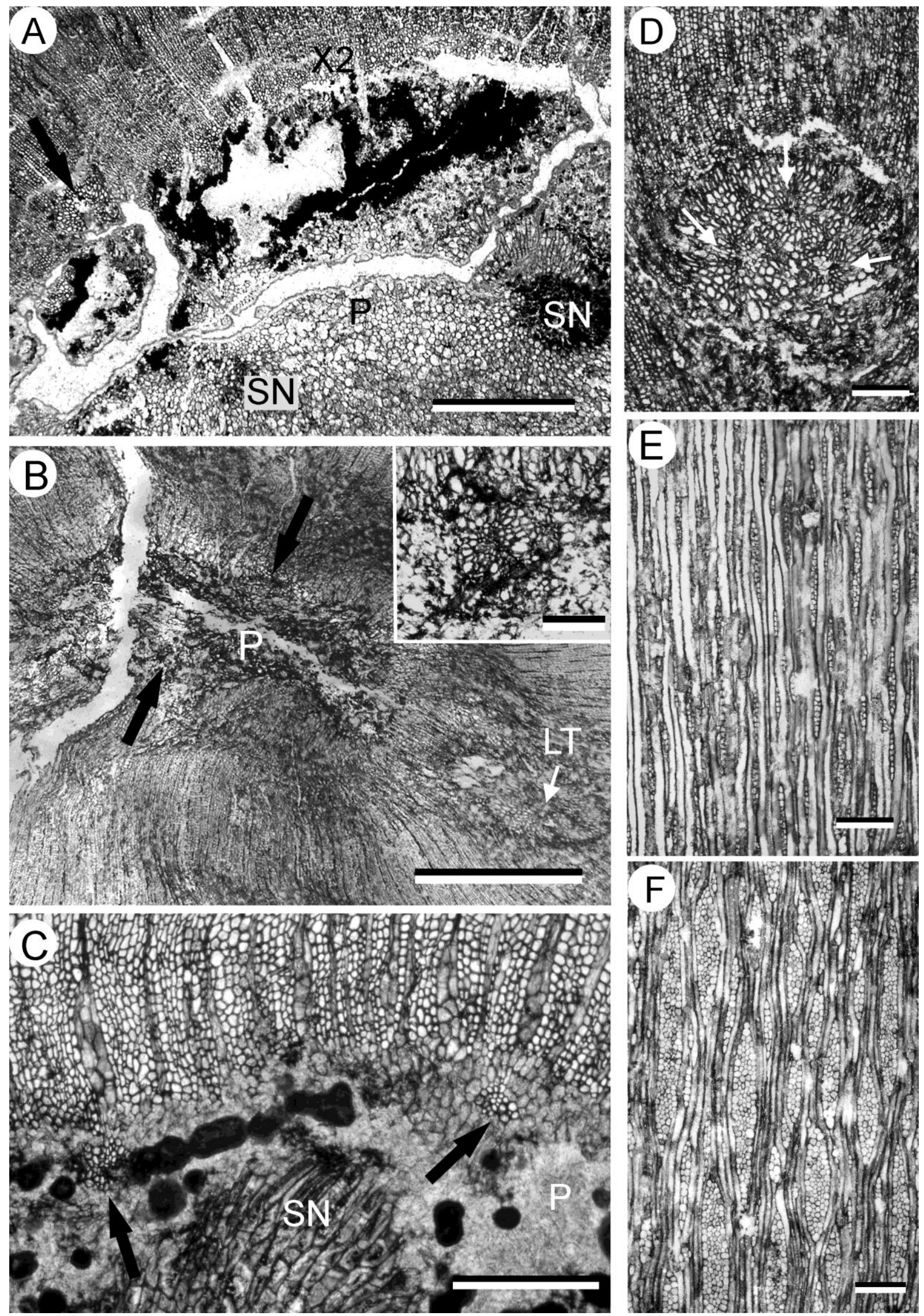
NOTICE: This is the author's version of a work accepted for publication by Elsevier. Changes resulting from the publishing process, including peer review, editing, corrections, structural formatting and other quality control mechanisms, may not be reflected in this document. Changes may have been made to this work since it was submitted for publication. A definitive version was subsequently published in Comptes Rendus Palevol, [VOL\#6, ISSUE 6-7, p.393-401], November 2007, DOI:10.1016/j.crpv.2007.09.011

\begin{tabular}{|c|c|c|c|c|}
\hline Species & Reference & Locality & Age & Type of fossil \\
\hline E. beinertianum & Goeppert, 1850 & Glätzisch-Falkenberg, Poland & V3? & Decorticated axis \\
\hline E. beinertianum & Scott, 1902 & Norham Bridge, Scotland & $\operatorname{Tn} 3$ & 1 decorticated axis \\
\hline E. beinertianum & $\begin{array}{c}\text { Barnard, } 1960 \text {; Long, } 1987 \\
\text { Bateman and Rothwell, } 1990\end{array}$ & Oxroad Bay, Scotland & $\operatorname{Tn} 3$ & Several decorticated axis \\
\hline E. beinertianum & Long, 1987. & $\begin{array}{c}\text { Burnmouth, Gin Head, Oxroad } \\
\text { Bay and West Blanerne, Scotland }\end{array}$ & & $\begin{array}{c}\text { axis - some associated with } \\
\text { Lyginorachis waltonii }\end{array}$ \\
\hline E. cf. beinertianum & Galtier and Scott, 1990 & Castleton Bay, Scotland & $\operatorname{Tn} 3$ & 1 decorticated axis \\
\hline E. fasciculare & Scott, 1902 & Loch Humphrey Burn, Scotland & V1-V2 & 1 decorticated axis \\
\hline E. fasciculare & Scott, 1902 & Haltwhistle, Scotland & Namurian A & 1 decorticated axis \\
\hline E. fasciculare & Galtier et al., 1993 & Weaklaw, Scotland & $\mathrm{V} 3$ & $\begin{array}{l}\text { Several axis - some with preserved } \\
\text { secondary phloem and periderm }\end{array}$ \\
\hline E. fasciculare & Galtier and Scott, 1994 & East Kirkton, Scotland & V3 & $\begin{array}{c}\text { Several axis }-2 \text { with secondary } \\
\text { phloem }\end{array}$ \\
\hline E. waltonii & Lacey, 1953 & Loch Humphrey Burn, Scotland & $\mathrm{V} 1-\mathrm{V} 2$ & 1 decorticated axis \\
\hline E. waltonii & Long, 1987 & Cove and Oxroad Bay, Scotland & Tn3 & $\begin{array}{c}3 \text { axis - one with petiole base cf. } \\
\text { Lyginorachis waltonii }\end{array}$ \\
\hline E. waltonii & Galtier and Scott, 1990 & Castleton Bay, Scotland & Tn3 & Several decorticated axis \\
\hline \multirow[t]{2}{*}{ E. cf. waltonii } & Galtier and Scott, 1990 & Castleton Bay, Scotland & Tn3 & 1 decorticated axis \\
\hline & Galtier et al., 1998 & Near Ilerthal, France & $\mathrm{V}$ & 1 trunk $30 \mathrm{~cm}$ wide \\
\hline Eristophyton $s p$. & Decombeix et al., 2005 & Kahlleite, Germany & $\operatorname{Tn} 2$ & 1 decorticated axis \\
\hline Eristophyton sp. & Galtier et al., 1998 & Bourbach-le-Bas, France & $\mathrm{V}$ & 1 wood fragment \\
\hline Dadoxylon (cf.Eristophyton) & Chalot-Prat and Galtier, 1989 & Tazekka, Morocco & Namurian & 1 trunk \\
\hline E. bajkaimicum & Lepechina, 1969 & Kuznetsk Basin, Russia & Upper Permian & decorticated axis \\
\hline E. zalesskyi & Lepechina, 1972 & Kuznetsk Basin, Russia & Lower-upper Permian & decorticated axis \\
\hline E. leninskianum & Lepechina, 1972 & Kuznetsk Basin, Russia & Upper Permian & decorticated axis \\
\hline Dadoxylon (Eristophyton) ibericum & Vozenin-Serra et al., 1994 & Sevilla region, Spain & Permian & 1 wood fragment \\
\hline
\end{tabular}

Table 1. Occurences of Eristophyton.

Tableau 1. Occurrences d'Eristophyton. 